\title{
REPRESENTASI MAKSIM PKS DALAM TUTURAN INTERAKSI PEMBELAJARAN BI DI KELAS XI SMA UNISMUH MAKASSAR
}

\author{
Abd. Rahman Rahim \\ Fakultas Keguruan dan Ilmu Pendidikan, Universitas Muhammadiyah Makassar \\ rahman_UMM@yahoo.com.
}

\begin{abstract}
PKS basic constructs systems were beyond the language used as the rational principles in communication. However, PKS language elements affect were the selection, arrangement, and interpretation communication. The essential of PKS system was a communication rules that were beyond language, but it could influence the selection of language elements, arrangement, as well as the interpretation of utterances. The speech acts can be delivered communicative, if the maxim of quantity, quality, relation, and manner considered by the speaker. Therw were four types of maxim, namely (a) violation (Violate), (b) neglect (opt out), (c) the clash (clash), and (d) the game (flout). Violete occur means that the participants said wrong using the maxim. This study was a qualitative approach is used because this study has the characteristics (1) has a natural background as a data source directly by using the researcher as the key instrument, (2) is a description, (3) concerned with process rather than outcomes, (4) using inductive data analysis, and (5) emphasize kebermaknaan.Penelitian is expected to resolve the problems of the Cooperation principle Violations
\end{abstract}

Key Words: Maxim, Cooperation principle

Abstrak

Konstruk dasar PKS berada di luar bahasa yang digunakan sebagai prinsipprinsip rasional komunikasi.Akan tetapi, PKS memengaruhi pemilihan unsur bahasa, penataan, dan penafsiran tuturan.PKS pada hakikatnya merupakan kaidah berkomunikasi yang berada di luar bahasa, namun dapat memengaruhi pemilihan unsur bahasa, penataan, serta penafsiran tuturan. Karena itu, tindak tutur itu dapat disampaikan secara komunikatif, apabila maksim kuantitas, kualitas, hubungan, dan cara diperhatikan oleh peserta tutur.Pelanggaran maksim tutur menjadi empat jenis, yaitu (a) pelanggaran (violate), (b) pengabaian (opt out), (c) perbenturan (clash), dan (d) permainan (flout). Pelanggaran (violete) terjadi karena peserta tutur tidak mampu menggunakan maksim secara benar.Jenis tulisan dalam karya tulis ilmiah ini adalah pendekatan kualitatif digunakan karena penelitian ini memiliki karakteristik (1) memunyai latar alamiah sebagai sumber data secara langsung dengan memanfaatkan peneliti sebagai instrumen kunci, (2) bersifat deskripsi, (3) mementingkan proses daripada hasil, (4) menggunakan analisis data secara induktif, dan (5) menekankan kebermaknaan.Penelitian ini diharapkan dapat menyelesaikan masalah tentang Pelanggaran Prinsip Kerjasama.

Kata Kunci: Prinsip Kerja Sama, Maksim. 


\section{PENDAHULUAN}

Sebuah komunikasi akan terjalin secara kmunikatif apabila ada kerja sama antara penutur dengan mitra tutur. Namun, percakapan tersebut akan terasa hambar, bahkan terjadi salah pengertian jika mitra tutur tidak memberikan tanggapan seperti yang diharapkan olh penutur. Untuk itulah, di dalam sebuah komunikasi harus ada kerja sama, yang di dalam ilmu bahasa dikenal dengan istilah maksim PKS atau Prinsip Kerja Sama. Komunikasi yang baik dalam pembelajaran tercipta apabila guru dan siswa menggunakan bahasa Indonesia yang benar secara struktural dan baik secara situasional. Namun, pembelajaran bahasa Indonesia umumnya berpusat pada pendekatan komunikatif, sedangkan aspek-aspek pragmatik yang dapat membangunkomunikasi kurang diperhatikan secara berimbang. Hal itu tercermin dalam pendapat Ibrahim (1993), bahwa komunikasi yang berlangsung pada banyak kelas masih jauh dari kondisi komunikasi yang ideal.

Prinsip Kerja Sama itu pada hakikatnya merupakan prinsipkomunikasi verbal yang berlaku secara umum dalam konteks dan latar manapun. Kajian ilmu bahasa ini muncul akibat adanya ketidakpuasan kaum pragmatik terhadap hasil analisis bahasa yang dilakukan oleh kaum strukturalis. Perhatikan contoh di bawah ini:

"Aminah menikahi Ali"

Secara strukturalis, kalimat tersebut benar karena terdapat Subjek, Predikat, dan Objek. Akan tetapi secara situasional, kalimat tersebut tidak diterima karena berada di luar kelaziman. Oleh sebab itu mengkaji bahasa harus memperhatikan konteks pemakaian atau situasi pragmatik. Sebagai prinsip rasional dalam komunikasi verbal, PKS mempunyai empat maksim dalam kajian Pragmatik, yaitu (1) kuantitas, (2) kualitas, (3) hubungan, dan (4) cara (Grice, 1975). Prinsip rasional PKS menurut Grice (1975) sesungguhnya berada di luar bahasa, namun dapat memengaruhi pemilihan unsur bahasa, penataan, serta penafsiran tuturan.Dengan demikian, PKS merupakan salah satu kajian pragmatik yang penting untuk dipahami dan diaplikasikan dalam berkomunikasi..

Pada umumnya masih sering terjadi hegemoni kekuasaan ketika terjadi interaksi pembelajaran di dalam kelas sehingga guru lebih mendominasi pembelajaran di kelas. Guru lebih memiliki power dan kontrol daripada siswa. Itulah sebabnya perlu dilakukan sebuah penelitian untuk mengungkap tentang wujud penerapan maksim PKS dalam pembelajaran Bahasa Indonesia. Dengan demikian diperoleh hasil yang 
representatif tentang wujud maksim PKS yang digunakan oleh guru sehingga dapat diberikan solusi cerdas untuk memaksimalkan hasil belajar yang dapat membawa siswa ke pemahaman kognitif yang maksimal dan berkarakter yang baik.

\section{METODE PENELITIAN}

\section{Jenis Penelitian}

Program penelitian ini dikategorikan ke dalam jenis penelitian deskriptif kualitatif, yaitu penelitian yang data-datanya dalam bentuk verbal atau ucapan.

\section{Sumber dan Data Penelitian}

\section{a. Sumber Data Penelitian}

Data penelitian bersumber dari interaksi verbal atara guru dan siswa sebagai bentuk kerja sama antara Pn dan Mt dalam konteks pembelajaran BI di kelas.

\section{b. Data Penelitian}

Data penelitian ini adalah wacana interkasional kelas yang mencakup tuturan verbal maupun tindak nonverbal.Dari wacana interaksional kelas itu diperoleh wujud penggunaan maksim PKS dalam komunikasi.

\section{Teknik Pengumpulan dan Analisis Data}

Teknik yang digunakan untuk mengumpulkan data penelitian ini ialah studi dokumentasi, observasi, perekaman, dan wawancara dan dianalisis dengan menggunakan metode deskriptif kualitatif.

\section{HASIL PENELITIAN}

\section{Realisasi Wujud Maksim PKS}

\section{a. Wujud Penggunaan Maksim Kuantitas}

Maksim kuantitas mengarahkan peserta tutur agar bertutur (a) secara informatif, (b) tidak terdapat unsur kalimat atau keterangan informasi yang berlebih-lebihan, dan (c) lengkap informasinya. Guru dan siswa menggunakan maksim itu secara nyata dalam tindak tutur pembelajaran BI di kelas. Paparan penggunaan maksim tersebut sebagai berikut.

Pada kegiatan awal pembelajaran BI guru meminta perhatian siswa, memberi salam dan siswa menjawabnya, lalu mengecek kehadiran siswa satu per satu. Penggunaan maksim itu tampak pada penggalan wacana berikut.

[1] G : Selamat pagi, semua! (1)

$\mathrm{S}$ : Pagi, Bu. (2)

G :Bagaimana kabarnya hari ini.

(3)

S : Baik, Bu. (4)

G : Dengarkan, ibu akan mengecek kehadiran kalian! (5)

S: Ya, Bu. (6) 
Penggalan wacana [1] merupakan bentuk interaksi guru-siswa pada kegiatan awal pebelajaran yang dibuka oleh guru dengan tindak apresif, yakni mengucapkan salam kepada siswa (1). Karena itu, siswa pun menjawabnya dengan jawaban yang sudah lazim (2).Atas alasan itu, guru memicu ulang lagi dengan tindak direktif, yaitu menanyakan kabar siswa.Pemicu ulang lanjutan itu terdiri atas tiga kata.Siswa menjawabnya dengan dua kata (3).Walaupun demikian, kuantitas informasi tuturan itu cukup memadai.Kata "Baik" merupakan jawaban siswa atas pertanyaan guru. Dengan pemahaman itulah, guru memicu ulang dengan tindak direktif, yaitu meminta langsung agar siswa mendengarkan nama masingmasing pada saat dipresensi (5).Permintaan guru cukup informatif bagi siswa, dengan tidak mengurangi kuantitas informasi. Informasi dalam permintaan itu ialah siswa mendengarkan guru. Siswa menjawabnya dengan tindak deklaratif secara verbal dengan jawaban "Ya,Pak".

(2) maupun nonverbal berupa sikap diam serta memperhatikan guru.

\section{b. Wujud Penggunaan Maksim Kualitas}

Maksim kualitas mengarahkan

guru dan siswa agar bertutur (a) benar/tidak mengandung kebohongan dan (b) didukung oleh teori yang benar.Guru/pegawai dan siswa menggunakan maksim itu secara nyata dalam tuturan interaksi pembelajaran BI di kelas.Penggunaan maksim kualitas dalam tuturan tersebut sebagai berikut.

Dalam interaksi guru-siswa maksim kualitas digunakan pada konteks topik Mengidentifikasi alur, penokohan, dan latar dalam cerpen dijelaskan oleh guru kepada siswa. Penggunaan maksim itu sebagaimana penggalan wacana berikut.

[2] G: Pada saat membaca cerpen, kamu perlu memperhatikan alur cerita. Yang dimaksud alur adalah sambung sinambungnya kejadian dalam cerita untuk mencapai efek tertentu.Susunan alur terdiri atas pembukaan, konflik, klimaks, antiklimaks, dan penyelesaian. Perhatikan gambar ini!(menggambar di papan). Kelihatan di belakang? (7)

S: Kelihatan, Bu. (8)

Dalam penggalan wacana [2] tuturan interaksi dibuka oleh guru dengan penjelasan tentang topik Menentukan Alur dalam Cerpen (7). Penjelasan itu difokuskan pada bagian-bagian alur. Oleh karena itu, penjelasan dimulai dengan konsep alur cerita.Agar dipahami oleh siswa, alur pembangun cerita digambarkan di papan tulis oleh guru. 
$\begin{array}{rrrr}\text { Dari } & \text { segi } & \text { maksim kualitas, } \\ \text { penjelasan } & \text { guru } & \text { itu benar/tidak }\end{array}$ mengandung kebohongan. Kebenaran itu sesuai dengan teori bahasa dan sastra.. Bunyi-bunyi lingual sesuai dengan fonologi BI baku. Kalimat deklaratif, imperatif, dan interogatif dalam tuturan benar menurut konteks BI baku. Ketiga kalimat benar-benar tindak representatif dan direktif (penjelasan, permintaan langsung, dan pertanyaan) menurut konteks interaksi pembelajaran. Dalam interaksi tersebut siswa pun menggunakan maksim kualitas dalam menjawab pertanyaan guru (8).Tuturan jawaban siswa benar secara fonologis maupun gramatikal. Bunyi lingual jawaban siswa sesuai dengan fonologi BI baku. Kalimat deklaratif dalam tuturan jawaban siswa benar menurut konteks interaksi pembelajaran dan sosiokultur sopan santun berbahasa di sekolah. Kalimat itu benar-benar merepresentasikan jawaban siswa. Tuturan siswa tidak mengandung kebohongan. Ketidakbohongan siswa sesuai dengan konteks yang benar, yakni siswa benar-benar melihat tulisan di papan. Hal itu didukung oleh kondisi mata siswa normal, menulis lancar, dan tidak ada yang menghalang pandangan siswa..Tindak tutur itu benar secara kebahasaan. Bunyi-bunyi lingual tuturan benar menurut fonologi BI baku. Kalimat deklaratif dan permintaan langsung benar secara gramatikal BI baku.

\section{c. Wujud Penggunaan Maksim Hubungan}

Maksim hubungan mengatur tuturan agar (a) kalimat-kalimatnya saling berhubungan dan (b) kalimatkalimatnya berhubungan dengan pembelajaran dan sosiokultur sekolah. Guru/pegawai dan siswa menggunakan maksim tersebut secara nyata dalam tindak tutur pembelajaran di kelas. Maksim hubungan digunakan dalam konteks topik Menarasikan Pengalaman ke dalam Bentuk Dialog dijelaskan oleh guru.Penggunaan maksim itu dapat dilihat pada penggalan wacana berikut.

[3] G: Perhatikan! Membuat teks drama dari pengalaman sendiri tidaklah begitu sulit. Hal itu dikarenakan tema, rangkaian cerita, dan latarnya sudah tersedia dalam pikiran kita sendiri. Kita hanya tinggal menceritakan kembali pengalaman itu ke dalam bentuk dialog-dialog. Pilihlah pengalaman yang melibatkan beberapa orang tokoh dan mengandung konflik yang kuat, namun sederhana. Sehingga teks drama dapat menjadi lebih hidup, ringan, 
dan membuat penasaran pembacanya.(9)

S: Betul, Bu. (10)

Dalam penggalan wacana [3], kalimat dalam tuturan (9) mempunyai hubungan. Hubungan itu tampak pada tersusunnya kalimat-kalimat. Ide setiap kalimat tersusun secara logis, runtut, dan tidak keluar dari topik materi pembelajaran. Demikian pula kalimat pada tuturan (10) mempunyai hubungan dengan kalimat-kalimat dalam tuturan (9), yaitu pembenaran terhadap penjelasan guru. Hubungan dari segi tindak tutur, tuturan itu tersusun atas tindak direktif, representatif, dan deklaratif (permintaan langsung, penjelasan, dan pembetulan). Maksim hubungan digunakan pula pada konteks pemberian soal-soal latihan oleh guru dan siswa. Penggunaan maksim tersebut terdapat pada penggalan wacana.

[4] G : Bacalah bacaan pada halaman 1, kemudian jawab soal-soal latihan halaman 1 sampai 3 ! Boleh dikerjakan secara berkelompok, dua atau empat orang. (11)

$\mathrm{S}$ : Dikerjakan di buku mana, Bu?

G : Di buku latihan. Kamu semua sudah mengerti? (13)

S: Sudah, Bu. (14)

G : Ya, bagus, silakan kerjakan!
Pada penggalan wacana [4] percakapan dibuka oleh guru dengan tindak direktif, yakni permintaan langsung agar soal-soal latihan dikerjakan oleh siswa (11). Tuturan itu terdiri atas dua kalimat yang saling berhubungan. Hubungan tuturan pada kalimat pertama ialah adanya kesetaraan ide membaca padaklausa pertama dan ide permintaan langsung menjawab pada klausa kedua. Kemudian, ide pertanyaan siswa (12), penjawaban dan pertanyaan balik guru (13), pengakuan siswa (14), serta pemujian dan permintaan langsung guru (15). Hubungan tindak tuturnya tersusun: direktif, deklaratif, ekspresif, direktif, dan representatif. Tuturan itu berhubungan secara runtut, logis, bermakna, serta sesuai dengan topik dan sosiokultur yang biasa dilakukan.Sapaan yang digunakan oleh siswa relevan dengan sebutan guru laki-laki di lingkungan sekolah.

\section{d. Wujud Penggunaan Maksim Cara}

Maksim cara mengatur agar tuturan guru dan siswa jelas dalam tindak tutur pembelajaran BI. Untuk mencapai kejelasan, maka tuturan guru/pegawai dan siswa harus memenuhi syarat submaksim cara, yaitu (a) tidak terdapat pernyataan yang samar, (b) tidak terdapat ketaksaan, (c) singkat, dan (d) kalimatkalimatnya teratur. Peserta tutur 
menggunakan maksim itu dalam tindak tutur pembelajaran BI di kelas.

Berdasarkan hasil analisis data, tuturan guru-siswa menggunakan maksim cara dalam konteks guru menjelaskan materi pembelajaran kepada siswa. Bukti penggunaan maksim itu tampak pada penggalan wacana berikut.

[5] G :Pokok bacaan pada awal paragraf, dinyatakan dalam kalimat pertama. Pokok bacaan itu kemudian dijelaskan atau dianalisis oleh kalimat-kalimat yang ada di bawahnya. Perhatikan contoh pada halaman 146! (16)

\section{S: Halaman 146. (17)}

Menurut penggalan wacana [5], guru membuka tuturan dengan informasi tentang konsep pokok bacaan pada awal paragraf melalui tindak representatif. Kemudian, guru melanjutkan dengan tindak direktif agar siswa membuka buku cetak. Kedua tindak tersebut merupakan tuturan untuk memahamkan siswa secara efektif. Untuk itu, guru menggunakan tuturan yang cukup jelas bagi siswa. Bagian-bagian tuturan tidak bermakna taksa. Tuturan guru tidak mengandung makna yang beragam, sehingga siswa tidak perlu menafsirkannya. Untuk melengkapi syarat kejelasan, tuturan guru pun tertata secara teratur. Keteraturan tuturan tampak pada segmental dan suprasegmental kalimat maupun penataan ide yang runtut dan logis menurut konteks.

Bukti jelasnya tuturan guru ialah siswa menjawabnya dengan tindak representatif secara verbal (16) dan nonverbal. Tindak verbal ialah halaman 146 dan nonverbal ialah tindak membuka buku cetak. Jawaban siswa pun memenuhi syarat kejelasan sehingga guru menerimanya dengan tindak nonverbal anggukan. Anggukan itu sama dengan tindak verbal "ya" (17)

Penggalan wacana

membuktikan tentang penggunaan maksim cara dalam pola interaksi siswasiswa pada konteks pemberian latihan tentang kata umum-khusus di papan tulis. Penggalan wacana ini sebagai berikut.

[6] S1: Unsur-unsur intrinsik hikayat itu apa ya? (18)

S2: Seperti halnya cerpen dan novel: alur, penokohan, latar, tema. (19)

S1: Itu ya. (20)

Menurut penggalan wacana [6], Yusril membuka tuturan interaksi secara jelas dengan pertanyaan kepada Fadlan menurut tindak direktif (18).Pertanyaan itu untuk memperkuat pendapatnya pada saat mendapat giliran menjawab soal latihan di papan tulis. Fadlan memberikan bantuan dengan jawaban informatif yang jelas dalam tindak representatif (19). Karena itu, Yusril menerimanya secara verbal (20). 


\section{Pembahasan}

Agar tidak salah dalam mentransfer suatu gagasan dan informasi kepada Mt atau sebaliknya, guru/pegawai dan siswa dapat menentukan strategi bertutur yang tepat. Strategi maksim kuantitas, kualitas, hubungan, dan cara merupakan sarana untuk berlatih menyampaikan pengetahun, keterampailan, dan sikap berbahasa Indonesia bagi guru/pegawai dan siswa. Ketiga domain itu dapat efektif apabila pilihan strategi keempat maksim PKS lebih apik menurut konteks komunikasi interaksi pembelajaran BI. Strategi maksim kuantitas mengarahkan guru dan siswa agar merangkai tuturan seinformatif mungkin. Strategi maksim kuantitas mengarahkan guru/pegawai dan siswa agar menggunakan tuturan sejalan isi hati yang sebenar-benarnya. Strategi maksim hubungan mengarahkan guru dan siswa agar merangkai tuturan secara koteks dan konteks interaksi pembelajaran. Strategi maksim cara mengarahkan guru/pegawai dan siswa agar mengungkapkan materi pembelajaran dengan jelas. Strategi yang dipilih merupakan cara yang digunakan oleh guru/pegawai dan siswa untuk menyampaikan pembelajaran BI. Strategi yang tidak tepat dalam bertutur dapat mengakibatkan kegagalan pembelajaran. Keberhasilan komunikasi interaksi pembelajaran bergantung pada pemilihan strategi yang tepat.

Fungsi maksim PKS dapat diaplikasikan di sekolah. Fungsi PKS dapat dijadikan acuan untuk mengetahui fungsi tuturan guru dan siswa. Penggunaan maksim PKS merupakan sarana pendidikan untuk memahami maksud- maksud tuturan dalam pembelajaran BI. Guru dan siswa dapat menentukan tuturan yang berfungsi mendukung dan menghambat komunikasi interaksi pembelajaran BI. Tuturan yang mendukung dan berimplikasi positif terhadap pembelajaran, itulah yang dikehendaki dalam maksim PKS, seperti yang dinyatakan oleh Ibrahim (1993), bahwa komunikasi yang berlangsung pada banyak kelas masih jauh dari kondisi komunikasi yang ideal..

\section{KESIMPULAN}

Berdasarkan hasil penelitian, dapat disimpulkan bahwa dalam pembelajaran Bahasa Indonesia di SMA Unismuh Makassar, guru menerapkan empat maksim PKS, yakni:(1) maksim kuantitas, (2) maksim kualitas, (3) maksim hubungan, dan (4) maksim cara. Dari wujud penerapan maksim tersebut diperoleh hasil bahwa: (1) guru dan siswa menggunakan maksim kuantitas itu secara nyata dalam tindak tutur pembelajaran BI pada kegiatan awal pembelajaran. (2) 
dalam interaksi guru-siswa maksim kualitas digunakan pada konteks topik Mengidentifikasi alur, penokohan, dan latar dalam cerpen dijelaskan oleh guru kepada siswa.(3) maksim hubungan digunakan dalam konteks topik Menarasikan Pengalaman ke dalam Bentuk Dialog dijelaskan oleh guru. dan (4) guru-siswa menggunakan maksim cara dalam konteks guru menjelaskan materi pembelajaran kepada siswa untuk mencapai kejelasan.

\section{REFERENSI}

Danim Sudarwan. 2010. Pengantar Pendidikan. Bandung: Alfabeta.

Sanjaya, Wina. 2010. Strategi Pembelajaran Berorientasi Standar Proses

Pendidikan.Jakarta: Kencana.

Saputra, Dimas. 2011. Maksim PKS (Prinsip Kerja Sama )Malang : Universitas Negeri Malang, Fakultas Ilmu Keguruan.

Paelori, Thamrin. 2005. Pembelajaran Keterampilan Berbicara Secara Kreatif dan Inovatif.Makalah, disampaikan dalam Simposium Pendidikan di Jakarta.

Rofi'uddin. 2002. Pragmatik. Jakarta: Gramedia. 